\title{
Collaborative Environmental Negotiation with Private Non- verifiable Information: An Experimental Test
}

\author{
Christopher Bruce (corresponding author) \\ Department of Economics \\ University of Calgary \\ 2500 University Drive N.W. \\ Calgary, AB, Canada, T2N 1N4 \\ 403-220-4093 \\ cjbruce@ucalgary.ca \\ Jeremy Clark \\ Department of Economics and Finance, \\ University of Canterbury, \\ Private Bag 4800 \\ Christchurch, New Zealand. \\ 643-364-2308 \\ jeremy.clark@canterbury.ac.nz
}

The experiments employed in this research were conducted at the University of Canterbury

Acknowledgments:

This work was supported by the Donner Canadian Foundation under Grant No. A-02-98; and the College of Business and Economics of the University of Canterbury. 


\title{
Collaborative Environmental Negotiation with Private Non-verifiable Information: An Experimental Test
}

\begin{abstract}
In many cases governments invite interest groups to use collaborative negotiation to resolve environmental conflicts. Characteristic of these negotiations is that the parties lack ex ante information about their opponents' ordinal and cardinal preferences. We argue in this paper that most laboratory experiments that have investigated the outcomes of collaborative negotiation have not taken this information asymmetry into account fully. In this paper, we devise, and implement, an experimental protocol that allows for a strong test of the effects of private information. We hypothesize that making information private will have only a limited effect on subjects' abilities to reach Pareto efficient bargains or on the effect that entitlements will have on the outcome; but that considerations of equity will become less important. We find evidence to support all three of these hypotheses.
\end{abstract}

Keywords: cooperative bargaining, environmental policy-making, private information, entitlement, Nash bargain, laboratory experiments

JEL Classifications: C92, D74, H44, Q58 


\section{Introduction}

Environmental conflicts can often be characterized as disputes among stakeholders over the allocation of public goods with multiple attributes. For example, forestry companies, ranchers, recreational users, and environmentalists may disagree both about the allocation of public lands among alternative uses and about the level of constraints to be placed on the use of those lands. Government agencies responsible for selecting policy in such cases face the problem that they lack credible information about the parties' preference functions, thereby impeding their ability to find Pareto optimal solutions.

In practice, this difficulty is often resolved through the use of collaborative negotiation ${ }^{1}$ in which stakeholders bargain with one another over the development of environmental policy. A prominent example of this process arises in the development of habitat conservation plans under the U. S. Endangered Species Act (Aengst et. al 1997; U.S. Fish and Wildlife Service 2005). Evidence that bargaining techniques are widely used in other situations is provided by Beierle (2000), who identifies 239 cases of collaborative decision-making; by Ansell and Gash (2007) and Reed (2008), who survey more than 250 scholarly studies; and by Lubell and Leach (2005) and Leach et. al. (2002), who report that in the United States there are over one thousand collaborative watershed partnerships.

\footnotetext{
${ }^{1}$ Also known as: cooperative bargaining, consensus-building, negotiated rulemaking, deliberative democracy, and mediated negotiation.
} 
Although the literature analyzing environmental collaborative negotiation is now extensive $^{2}$, researchers have had limited success testing many of their fundamental hypotheses, primarily because information about stakeholders' preferences is private, making observers unable to determine whether the outcomes reached are consistent with their hypotheses. Instead, researchers have had to use second-best criteria, such as whether parties have been able to reach agreement (Bierle, 2000), whether there are measurable improvements in specified characteristics of the environment (Kenney 2000; Leach, Pelkey, and Sabatier 2002), or whether outcomes have been challenged in court (Coglianese 1997).

To resolve this measurement problem, we employ controlled laboratory experiments that mimic two of the most important features of environmental bargaining: (i) that many environmental policies are composed of multiple attributes, allowing stakeholders to "trade" among attributes; and (ii) that negotiators do not possess credible information about one another's preferences, preventing them from identifying Pareto improving trades directly.

We find that, as predicted by proponents of collaborative negotiation, our subjects are able to reach agreement on outcomes that are at or near Pareto efficiency in an encouragingly high percentage of cases. We also find that considerations of equity have inconsistent effects on negotiated outcomes under private information, being significant in some cases but not in others. Finally, we find that entitlement effects have a robust, significant impact on negotiated outcomes. Together these results suggest that environmental collaborative bargaining is capable of yielding efficient policies. These policies are likely to be influenced, however, by considerations of entitlement and, to a lesser extent, by equity.

${ }^{2}$ Despite the size of this literature, collaborative negotiation has been virtually ignored by economists. For two exceptions see Rhoads and Shogren (2001) and Bruce and Clark (2010). 
The paper is organized as follows. In Section 2 we establish the hypotheses to be tested and derive an experimental design. In Section 3 we describe our experiment; while in Section 4 we present our results. Section 5 concludes with a brief discussion of the potential for using collaborative stakeholder negotiations to create environmental policy.

\section{Design of the Experimental Protocol}

We develop our experimental approach in three stages. First, we identify the salient characteristics of the collaborative negotiation process and employ those characteristics to construct a simple model. Second, we derive from that model a number of testable hypotheses concerning the outcomes of collaboration. Finally, we design an experimental protocol that is particularly suited to the testing of our hypotheses.

\subsection{Characteristics}

The procedures referred to as collaborative negotiation in the literature on environmental policy making are characterized by three attributes. First, the policies in question are composed of multiple elements, as it is only in this situation that mutually advantageous concessions can be obtained. For example, assume that an order made under the Endangered Species Act (ESA) specifies the number of acres that are to be protected, the location of those acres, and the level of protection that is to be provided. A landowner might be willing to accept tighter restrictions on use of his land if environmental groups agreed, in return, to a reduction in the amount, or location, of the land under regulation.

Second, if the parties fail to reach agreement, they face a backstop position. In those cases in which the government has invited stakeholders to negotiate an improvement on the 
existing policy, the backstop may simply be maintenance of the status quo. In other cases, however, the government may have announced that if the parties fail to reach agreement it will impose an allocation of resources that differs from the status quo. ${ }^{3}$ For example, this is, effectively, the situation when the U.S. Fish and Wildlife Service makes an order under the ESA and then invites stakeholders to construct a habitat conservation plan based on that order.

The parameters of the negotiation process that will arise when these characteristics are in place can usefully be represented by an Edgeworth box diagram, such as Figure 1. In that figure, we assume that two stakeholder groups, environmentalists and developers, disagree about the number of acres of public or private land that should be set aside as environmental preserve, A, (for example, for protection of an endangered species), and about the strength of restrictions, R, that should be placed on A. Assuming that both parties have convex preferences and that the government has indicated that the backstop will be the combination identified by $B$ in Figure 1 , the set of Pareto improving outcomes is represented in that figure by the area between the parties' indifference curves through $B$; and the set of Pareto efficient outcomes is represented by segment $J K$. Figure 1 also identifies $Q$, the status quo allocation, and the bargaining lens associated with $Q$, to represent the situation in which the government has chosen a backstop that differs from $Q$.

\section{Insert Figure 1 near here}

Finally, the parties to environmental collaboration have no direct information concerning their opponents' preference functions. At best, stakeholders might have some knowledge of an opponent's ordinal ranking of a single attribute - they might know, for example, whether an that

\footnotetext{
${ }^{3}$ This is the approach set out in the United States Negotiated Rule Making Act. See, for example, Pritzker and Dalton (1995); and Lubbers (2007-2008).
} 
party prefers more clean water to less. But they cannot be expected to have direct knowledge of cardinal preferences and will not be able to identify their opponents’ ordinal preferences among combinations of attributes. For example, even if developers could determine that environmentalists preferred $A_{2}$ to $A_{1}$ and $R_{2}$ to $R_{1}$ in the example above, it is unlikely that they would have ex ante knowledge about environmentalists’ ranking of $\left(A_{1}, R_{2}\right)$ versus $\left(A_{2}, R_{1}\right)$.

\subsection{Testable Hypotheses}

Most bargaining models predict that if the parties described in Figure 1 are faced with backstop $B$, they will negotiate to a Pareto efficient outcome, along JK. Nash (1950) in particular predicted that that outcome would maximize the product of the parties' gains relative to the backstop. The resulting Nash bargain is represented by $N$ in Figure 1.

Nash's model required that the parties have full information about one another's preferences, an unrealistic assumption in collaborative negotiation. However, Harsanyi (1977), building on earlier work by Zeuthen (1930), has shown that two negotiators could reach the Nash bargain even if neither was well-informed about the other's preferences. In his model, negotiators play a "brinkmanship" game in which both attempt to commit themselves to their current positions. The impasse that would result is resolved when the party that is less willing to accept the risk of a collapse of negotiations makes a concession. Harsanyi argued that if this risk is defined as the ratio of the cost of accepting the other party's offer to the cost of accepting the backstop position, the parties will alternate making concessions until they reach the Nash bargain. Hence, even in the presence of incomplete information about their opponents' preferences, the parties to collaborative negotiation will be drawn to Pareto improving policies, in the region of the Nash bargain. 
A number of authors - notably, Nydegger and Owen (1975), Roth, Malouf, and Murnighan (1981), Hoffman and Spitzer (1985), Shogren (1997), and Bruce and Clark (2011) have argued, however, that negotiators may be drawn away from the Nash bargain if the latter differs from the policy that would equalize the parties’ payoffs. On one hand, Fehr and Schmidt (1999) and Bolton and Ockenfels (2000) have argued that such results are consistent with the assumption that negotiators are averse to inequality. On the other hand, it has been recognised that parties may have difficulty reaching equitable outcomes under private information. One argument, presented by Roth and Malouf (1979), Roth, Malouf, and Murnighan (1981), Hoffman and Spitzer (1985), and Rhoads and Shogren (2003), is that subjects in a private information game can disguise the motive for their offers, forestalling retaliation from opponents who might object to offers based strictly on self-interest. It may also be argued that even if the parties prefer to obtain equitable outcomes, they will be unable to do so if they cannot compare payoffs. For both reasons, we predict that, in the presence of private information, egalitarian ideals will have little influence on the outcomes of collaborative bargaining. ${ }^{4}$

Finally, Bruce and Clark (2011) argue that both the focal point (Schelling 1960; Bazerman 1985; Binmore, Shaked, and Sutton 1989) and entitlement (Nozick 1974; Zajac 1995; Gachter and Riedl 2005) literatures suggest that if the status quo allocation, $Q$, differs from the backstop, $B$, bargainers may be drawn towards outcomes defined by $Q$ rather than by $B$. In this case, if the policy that has been in place historically differs from the new government backstop, parties’ feelings of status quo “entitlement” might become a third argument in bargainers' preference functions. If collaborative negotiation follows the process described by Harsanyi,

\footnotetext{
${ }^{4}$ Note: We test only for parties’ views concerning equity, not “fairness.” For the latter, see
} Keisner et. al. (2013). 
such entitlement effects might come into play even when the parties have private information. In Harsanyi's model, if party F believes it is entitled to a particular position, its cost of conceding to any offer by opponent $G$ will rise, which in turn raises F's bargaining power. As this unwillingness to concede is independent of F's information concerning G's preferences, we predict that such information should not affect qualitative predictions concerning entitlement.

Summarizing, we posit three testable hypotheses concerning the outcomes that will be reached under collaborative negotiation over environmental policy:

- Efficiency: The parties will negotiate "towards" the Nash bargain, $N$.

- Entitlement: The parties will negotiate to a Pareto efficient allocation within the bargaining lens conditioned on $Q$, not on $B$.

- Equity: The parties will be unable or unwilling to negotiate to the Pareto efficient allocation at which payoffs are equalized, $E$.

\subsection{The Experimental Protocol}

One method of testing our hypotheses experimentally would be to offer subjects a set of Pareto efficient outcomes, such as those along curve $J K$ in Figure 1, and ask them to agree upon one of those outcomes subject to the constraint that if they failed to reach agreement, they would receive a backstop outcome, say $B$ in Figure 1 . Implicitly, this is the protocol used in virtually all tests of the Nash bargain ${ }^{5}$ and of Coase bargaining ${ }^{6}$. For a number of reasons, we argue that this approach is inappropriate for the testing of hypotheses concerning collaborative negotiation.

\footnotetext{
${ }^{5}$ See, for example, Nydegger and Owen (1975), Roth and Malouf (1979), Roth, Malouf, and Murninghan (1981), Roth and Schoumaker (1983), Mehta, Starmer, and Sudgen (1990), and Murningham, Roth, and Schoumaker (1988).
} 
First, an experiment in which subjects are asked to choose among, say, ten Pareto efficient outcomes and one inefficient one (the backstop) offers only a very weak test of the prediction that collaborative negotiation over multi-faceted issues will lead stakeholders to select a Pareto efficient outcome. Even if negotiators select outcomes at random, they will choose an efficient outcome in ten cases out of eleven. Instead, a much more challenging test is provided if subjects are offered hundreds of options from which to choose, all of which are Pareto improvements on the backstop, but only a small subset of which are Pareto efficient.

Second, as we argued above, the literature on collaborative negotiations presumes that environmental policies are multi-faceted. Hence, the bargaining process is assumed to be one in which negotiators recombine attributes of those policies in ways that are successively Pareto improving. Thus, if all of the possible outcomes but one are efficient, an experiment cannot test whether subjects are able to recognise or create offers that move the parties towards a Pareto efficient outcome.

Finally, when subjects are asked to select an outcome from among a set of Pareto efficient possibilities, it is difficult to prevent individuals from guessing the ordinal ranking of their opponents’ preferences. For example, when Roth and Malouf (1979) asked subjects to divide a given set of counters, they disguised parties' payoff functions by giving each subject private information about the rate at which counters would be converted to dollars. In such a

${ }^{6}$ In this literature, the backstop position is chosen either by the experimenter or by one of the subjects, (the "controller"). The parties are then given the opportunity to select an alternative outcome, with a higher total payoff than at the backstop, if they can agree how to divide that payoff. See, for example, Hoffman and Spitzer (1982, 1985, 1986), Harrison and McKee (1985), and Rhoads and Shogren (2003). 
case, however, subjects could be expected to assume that their opponents' preferences were an increasing function of the number of counters they obtained; that is, an ordinal ranking could be guessed. But we argue that the parties to collaborative negotiations can have only limited information about ordinal rankings when the policies under consideration are composed of multiple attributes.

In the face of these problems, we believe that a rigorous test of collaborative negotiation requires both that subjects be asked to trade among multiple goods and that they be provided only with private information about payoffs. We have been able to identify only a small number of experiments that meet these criteria. In the experimental literature on commercial contracts, subjects are often asked to negotiate contracts that have numerous characteristics, such as delivery time, discount terms, and financing terms (Bazerman, Magliozzi, and Neale 1985; Murnighan et. al. 1999). But in all such cases that we have been able to identify, the payoff functions presented to the participants were linear, implying that the efficient contracts were corner solutions. Effectively, this reduces the difficulty of identifying the efficient set to such an extent that we question whether it truly tests parties' abilities to trade concessions. We recommend, instead, that subjects be given non-linear payoff functions, implying declining marginal utility from the available goods. Although this approach was recently employed by Bruce and Clark (2011), they implemented a full information design unlikely to hold in collaborative negotiation.

Accordingly, we base our experiments on the classic Edgeworth box diagram, such as Figure 1. Specifically, we present each of two subjects with his or her own payoff table generated from a Cobb-Douglas function over two goods, $\mathrm{X}$ and $\mathrm{Y}$. The first individual is assigned the initial allocation $\left(\mathrm{X}_{1}, \mathrm{Y}_{1}\right)$ and the second the allocation $\left(20-\mathrm{X}_{1}, 20-\mathrm{Y}_{1}\right)$. Subjects are 
then given a limited amount of time of face-to-face unstructured bargaining to negotiate a reallocation of these goods. If they reach an agreement, each receives the associated payoff from his or her table; otherwise each receives the payoff associated with the backstop. We incorporate private information into the unstructured bargaining by taking a number of steps to prevent subjects from revealing their payoff information to each other, in order to reflect our assumption that although stakeholders in environmental bargaining meet face to face, they lack credible information regarding one another's preferences.

In this setting we are able to determine whether parties who are faced with hundreds of possible outcomes, only a handful of which are Pareto efficient, and who have virtually no knowledge of their opponents' preference functions, will be able to reach Pareto improving agreements. Furthermore, we are able to identify the effect of separating equitable outcomes from the Nash bargain, and of separating the initial allocation of resources, ( $Q$ in Figure 1), from a backstop chosen by the experimenter, $(B)$.

\section{Experimental Design}

\subsection{Structure of the Experiment}

We recruit subjects in groups of ten, and give each an induced value payoff function over two abstract goods, $X$ and $Y$. Five subjects (denoted here for exposition as “environmentalists”) are assigned one payoff function, and five (“developers”) another, based on their prior choice of seat in the room. To generate convex preferences, we use Cobb Douglas payoff functions to map from X,Y allocations to experimental currency:

$$
\begin{aligned}
& \text { Experimental Currency }_{E n v}=a_{E n v} X_{E n v}{ }^{\alpha} Y_{E n v}{ }^{1-\alpha}+b_{E n v} \\
& \text { Experimental Currency }_{D e v}=a_{D e v} X_{D e v}{ }^{\alpha} Y_{D e v}{ }^{1-\alpha}+b_{D e v}
\end{aligned}
$$


The contract curve created by these preferences is a diagonal line with constant total payoffs. Each individual of type $i$ is endowed with an integer allocation $\left(X_{i, Q}, Y_{i, Q}\right)$, with the total quantity of $X$ and $Y$ set at 20 units each. Across all treatments, we set the backstop $B$ at $\left(X_{E n v, B}, Y_{E n v, B}\right)=$ $(18,7)$ and $\left(X_{D e v, B}, Y_{D e v, B}\right)=(2,13)$, or for brevity, $(18,7) /(2,13)$. As a result, the portion of the contract curve within the bargaining lens defined by $B$ lies between $\left(X_{E n v}, Y_{E n v}\right)=(12,12)$ and $\left(X_{E n v}, Y_{E n v}\right)=(14,14)$. Because risk preference is thought to influence bargaining outcomes (Murnighan et al. 1988), we elicit subjects’ risk attitudes using the method of Holt and Laury (2002) before giving them bargaining instructions.

After reading general instructions about the bargaining to take place, subjects are seated across from each other in pairs, one environmentalist with one developer. Each is then given specific instructions and a payoff table (denominated in experimental currency) for the first bargaining round. The payoff tables are fixed to immoveable lecterns, and thus cannot be revealed to opponents. While studying the instructions and payoff table, subjects are each privately shown a personalized slip of paper with their exchange rate from experimental currency payoffs to real (New Zealand) dollars for that round. To keep the experimental currency functions constant across treatments, our individual exchange rates need to contain both a multiplicative and additive term ${ }^{7}$, or

$$
\begin{aligned}
& \text { Real Payoff }_{E n v}=c_{E n v}{\text { Experimental Currency }+d_{E n v}}_{\text {Real Payoff }}=c_{D e v} \text { Experimental Currency }+d_{D e v}
\end{aligned}
$$

After studying their own instructions and payoff tables (denominated in experimental currency), and knowing their individual exchange rates, each pair is allowed a four minute period of unstructured bargaining in which they can discuss mutually acceptable integer allocations of $X$

\footnotetext{
${ }^{7}$ In practice, it was only the additive term that varied for subjects across treatments/rounds.
} 
and $Y$. Agreements have to be technically feasible, and described by one party on a form, and counter-ticked by the other with a different colored ink.

After the first bargaining round, decision slips are collected and recorded, half of subjects change seats, and each is given instructions, a payoff table, and a new currency exchange rate for the next round. This is repeated to create four rounds in total, with each round corresponding to one of our four treatments. Across sessions, we systematically varied the sequence of treatments among the eight possible orders in which every subject's exchange rate changes between every round. ${ }^{8}$ Subjects are instructed at the outset not to reveal their exchange rate to others. While this restriction is not in practice enforceable during bilateral bargaining, our design tries to ensure it cannot be breached in a credible way, just as in actual collaborative negotiations.

To control for wealth effects on risk preference, only one of the four rounds is implemented at the end of a session, chosen by the throw of a die. Consistent with common rules for environmental collaborative negotiation, we prevent credible offers of cash side payments after the experiment by (i) ensuring that total earnings are constant along the contract curve and (ii) using a different, privately held random draw for each person when being paid to determine which round to count.

Logistically, during the risk elicitation phase, the ten subjects per session are seated at widely spaced individual tables in two rows, with an empty row in between adjacent to the back row. At the beginning of the bargaining phase, the front row of subjects (unbeknown to them, all of one type) is turned around and seated at empty tables across from their first set of opponents. There are thus two tables separating each member of the bargaining pair. In subsequent rounds

${ }^{8}$ Sessions were therefore run in the orders (I, III,II, IV),(I, IV, II, III), (II, III, I, IV), (II, IV, I, III), (III, I, IV, II), (III, II, IV, I), (IV, I, III, II) and (IV, II, III, I), then repeated. 
the two types alternate in having to switch one table to the right. (One implication of this design is that subsequent panel regression analysis of bargaining outcomes will follow an individual of one type as he/she interacts with four different subjects of the other type.) Our design is unusual in that subjects are allowed full, virtually unrestricted communication with their opponents during each four minute round. They are warned that threatening or abusive language will not be tolerated, and each pair's conversation is recorded with a micro-cassette player located midway between them to one side of the tables. While this unstructured, face to face communication introduces "uncontrolled aspects of social interaction" (Roth 1995) and minimizes "social distance” (Hoffman, McCabe and Smith 1996), it also parallels the in-person, unstructured negotiation used in most forms of government-sanctioned collaborative negotiation.

\subsection{Design Features of the Treatments}

All four treatments are implemented in every session, one in each round. These treatments each present subjects with similar payoff tables, but vary the personal exchange rates so as to vary the location of the status quo allocation $Q$ and the inequality of payoffs at the Nash bargain in a 2x2 design. More formally, using our experimental payoff functions (1) and (2) and exchange rates (3) and (4), in all treatments we choose the $a$ 's, $b$ 's, $\alpha$, $c$ 's and d's to keep constant the following:

1. the size of the Edgeworth Box: $X_{E n v}+X_{D e v}=20$ and $Y_{E n v}+Y_{D e v}=20$

2. the size of the bargaining lens (55 cells)

3. the $B$ allocation: $\left(X_{E n v B}, Y_{E n v B}\right)=(18,7)$ and $\left(X_{D e v B}, Y_{D e v B}\right)=(2,13)$.

4. the $N$ allocation: $\left(X_{E n v N}, Y_{E n v N}\right)=(13,13)$ and $\left(X_{D e v N}, Y_{D e v N}\right)=(7,7)$

5. the sum of real payoffs at $B$ :

$$
c_{E n v}\left[a_{E n v} 18^{\alpha} 7^{1-\alpha}+b_{E n v}\right]+d_{E n v}+c_{D e v}\left[a_{D e v} 2^{\alpha} 13^{1-\alpha}+b_{D e v}\right]+d_{D e v}=\$ 28.77
$$


6. the sum of all contract curve payoffs, including at $N$ or $E$ :

$$
c_{E n v}\left[a_{E n v} 13^{\alpha} 13^{1-\alpha}+b_{E n v}\right]+d_{E n v}+c_{D e v}\left[a_{D e v} 7^{\alpha} 7^{1-\alpha}+b_{D e v}\right]+d_{D e v}=\$ 45.50 .
$$

To ensure adequate bargaining incentives, we set the parameters to ensure that the total payoffs are substantially higher along the contract curve (including $N$ or $E$ ) than at $Q$ or $B$.

To simplify the presentation of experimental currency payoffs, each subject is provided a colored payoff table showing the specific earnings he or she would receive for all feasible combinations of $X$ and $Y$. The "nominal" payoff that subjects would receive for a given allocation is identical across treatments, making the tables they receive on each round similar though not identical. ${ }^{9}$ Experiment parameters are reported in Table 1. In treatments where $Q$ and $B$ are identical, they are identified on a payoff table as a single yellow cell. In treatments where they differ, $Q$ and $B$ are identified by green and red cells, respectively. A sample payoff table for an environmentalist in Treatment II is provided in Figure 2.

\section{Insert Table 1 near here}

\section{Insert Figure 2 near here}

Treatment $I$. Treatment I is our control, with no divergence between $Q$ and $B$, at $(18,7) /(2,13)$, nor between $N$ and $E$, at $(13,13) /(7,7)$. The real payoffs for the environmentalist and developer are approximately equal at $Q=B$, ( $\$ 14.67$ and $\$ 14.10$, respectively), and exactly equal at $N=E$ (\$22.75 each). Both the Nash and egalitarian hypotheses predict that the parties will agree to $N$;

${ }^{9}$ The experimental currency payoff tables have different boundaries in Treatments I/II vs. Treatments III/IV because changes in exchange rates mean peripheral allocations that yield both parties positive real earnings in one treatment may yield one party negative earnings in another. Treatments I/II have 199 eligible allocations, while Treatments III/IV lose 63, but gain 79, yielding 215 eligible allocations. Calculators were provided for each person. 
the entitlement hypothesis predicts only that the parties will settle on the contract curve within the lens. This would include $N$ or the adjacent Pareto efficient allocations $(12,12) /(8,8)$ and $(14,14) /(6,6)$.

Treatment II. In Treatment II, $Q$ is separated from $B$, but all other parameters are unchanged from Treatment I. Q shifts “south-west,” from $(18,7) /(2,13)$ to $(16,4) /(4,16)$, yielding unequal real initial values for the environmentalist and developer of $\$ 0.00$ and $\$ 27.30$, respectively. ${ }^{10}$ Note that $Q$ lies outside the bargaining lens created by $B$, so that an environmentalist is better off at every point within the bargaining lens associated with $B$ than he or she is at $Q$, whereas the developer is worse off. In Treatment II the Nash and egalitarian hypotheses still predict agreement at $N=E$, but the entitlement hypothesis predicts that agreements will move south-west along the contract curve to lie within the "historical bargaining lens" formed by $Q$, reflecting the developer’s initial advantage.

Treatments III and IV. Treatments III and IV replicate the Treatment I/II comparison, but with $E$ separated from $N$. The physical locations of $Q, B$ and $N$ remain as in Treatments I and II; but the exchange rates change so as to shift the location of $E$ south-west, to $E^{*}$, at $(10,10) /(10,10)$. At this allocation real earnings are equalized at $\$ 22.75$ each, whereas at $N$ the environmentalist and developer would earn $\$ 36.40$ and $\$ 9.10$, respectively. Unfortunately, the introduction of unequal real payoffs at $N$ simultaneously requires the introduction of unequal real payoffs at $B$, with \$28.32 and \$0.45 for the environmentalist and developer, respectively. Faced with this confound, in Treatment IV we elect to equalize real payoffs at $Q$ at $\$ 13.65$ each. In this way, by comparing Treatments I and II we test whether an unequal initial $Q$ derails agreements to an

10 If this allocation had been the backstop, the Nash bargain would have occurred at $(10,10) /(10,10)$, with payoffs of $\$ 9.10$ and $\$ 36.40$ respectively. 
equal $N$ conditioned on an equal $B$; whereas by comparing Treatments III and IV we test whether an equal $Q$ derails agreements to an unequal $N$ conditioned on an unequal $B$.

The Nash bargaining hypothesis for both Treatments III and IV is that the parties will agree to $N$. The egalitarian hypothesis is that they will agree to $E^{*}$. The entitlement hypothesis is that the parties will agree to a Pareto efficient allocation within the bargaining lens defined by $B(=Q)$ in Treatment III as in Treatment I, but by $Q$ in Treatment IV as in Treatment II.

\section{The Results}

Sixteen experiment sessions with ten subjects each were run at the University of Canterbury. Our within-subject design resulted in 80 decision pair outcomes for each of Treatments I, II, and III and 78 for Treatment IV (as two pairs were given faulty payoff tables in one round). Each outcome consisted of a division of $\mathrm{X}$ and $\mathrm{Y}$ between the parties, $\left(X_{E n v}, Y_{E n v}\right) /\left(X_{D e v}, Y_{D e v}\right)$, and their real earnings. Each session took roughly 90 minutes, and subjects earned on average NZ \$22.27 $(1.00 \mathrm{NZ} \$=0.75 \mathrm{US} \$)$.

To provide some intuition, our results are summarized graphically in Figure 3 by treatment. We divide our discussion of results as follows. We begin by comparing agreement rates and proximity to Pareto efficiency across treatments. We then characterize the location of agreements in each treatment, and test whether the Nash, egalitarian, or entitlement hypotheses can explain changes observed in agreements across treatments.

\subsection{Agreement Rates and Proximity to Pareto Efficient Outcomes}

Our results suggest that even under private information, with as many as two hundred options facing them, subjects were able in most cases to reach agreements that were approximately 
Pareto efficient. As reported in Table 2, agreement rates ranged between 72 and 85 percent by treatment overall. They also rose slightly with experience over rounds/treatments, to the range of 80 to 95 percent by Round 4. Agreement rates appeared slightly lower when $Q$ differed from $B$, falling from 85 percent in both Treatments I and III, to 72 to 73 percent in Treatments II and IV.

In contrast, agreement rates did not appear affected by inequality at $B$ or $N$ (I vs. III or II vs. IV). To test formally for treatment effects on agreement rates (and on all subsequent outcomes of interest), we use non-parametric tests as well as panel regressions that follow individual environmentalists over rounds. For non parametric tests, we take each of our 16 session-averaged agreement rates for a given treatment as independent observations, and then compare agreement rates for any two treatments using a paired sample two-tailed signed rank test. These find that the drop in agreement rate caused by $Q$ diverging from $B$ was not significant at the 5 percent level when Nash payoffs were equal (I vs. II, $p=.23$ ), but was significant when Nash payoffs were unequal (III vs. IV, $p=.04$ ). For panel regression-based tests, we use random effects logit regressions of the likelihood of each bargaining pair reaching agreement on treatment, round, and order dummies, as well as pair demographics such as age or GPA measured either as averages or differences. ${ }^{11}$ We then test whether the coefficients on any two treatment dummies differ. As in the non parametric tests, the drop in agreement rates caused by $Q$ diverging from $B$ was not significant when the Nash payoffs were equal (I vs. II, $\mathrm{p}=.054$ ),

\footnotetext{
${ }^{11}$ All regressions are reported in Appendix B. Pair demographics include risk preference, age, sex, ethnicity, economics and math courses taken, self-reported GPA, and English first language. Specifications and tests were run with and without demographics, with very similar results regarding treatment effects.
} 
but now also missed significance when Nash payoffs were unequal (III vs. IV, $\mathrm{p}=.083$ ). ${ }^{12}$ Using analogous non parametric and panel regression tests, we find that agreement rates were not affected by making the Nash payoffs unequal rather than equal (I vs. III or II vs. IV).

\section{Figure 3 near here}

\section{Table 2 near here}

Turning to whether the agreements reached were Pareto efficient, Table 2 reports that by the third round of bargaining only about a third were precisely on the contract curve for most treatments. We think, however, that a superior test comes from measuring the physical or earnings deviation of agreements from the contract curve. This is because allocations immediately adjacent to the contract curve offered additional options for distributing payoffs with little cost in joint earnings. Beginning with physical deviations, we measure the Euclidean distance of agreements from the nearest Pareto efficient allocation. To illustrate magnitudes, an agreement one diagonal unit from the contract curve is 1.41 units away; an agreement two units from the curve is 2.83 units away, and $B$ is 7.78 units away. As reported in Table 3 , we find that agreements in all treatments are close to the contract curve. Overall average distance ranged from 1.00 in Treatment I, to 1.65 in Treatment II, with no pair-wise difference between treatments significant at the 5 percent level in either sign rank or regression-based tests.

Similar support for Pareto efficiency comes from measuring the shortfall in joint earnings of pairs from the NZ\$45.50 available on the contract curve. Again to illustrate magnitudes, an agreement one diagonal unit from the contract curve would reduce joint earnings by $\$ 0.46$ -

12 These $\mathrm{p}$ values are from the regressions using pair averaged demographic characteristics, which had a better fit. The $p$ values based on pair differenced characteristics are .045 (I vs II) and .076 (III vs. IV). 
$\$ 0.51$ depending on where it occurred. An agreement two units away would cost \$1.84 - \$2.03, while $B$ would cost the pair $\$ 16.73$. We report in Table 3 that the average joint shortfall in earnings ranged from $\$ 0.50$ in Treatment I, to $\$ 1.69$ in Treatment II. As with distance, we did not find any pair-wise difference between treatments to be significant.

\subsection{Treatment Results}

In this section, we identify and compare the results of each of the four treatments. In Section 4.3, we summarize the relative success of the Nash bargain, entitlement, and equity factors in predicting the agreements reached. For these purposes, we define three key measures:

- The Euclidean distance between each agreement and the Nash bargain, $N$, (at which payoffs are also equalized in Treatments I and II).

- The Euclidean distance between each agreement and $E^{*}$, the outcome that equalizes payoffs in Treatments III and IV, $(10,10) /(10,10)$.

- An index of the relative earnings shares of the two parties at each agreement versus what the shares would have been at the two key allocations. ${ }^{13}$ This index takes the absolute difference between the environmentalist's share of earnings at the actual agreement and at $N$, and subtracts from it the absolute difference between the environmentalist's share at the agreement and $E^{*}$. It can range from -0.3 , where a pair's division of earnings corresponds exactly to that at $E^{*}$, to +0.3 , where it corresponds exactly to that at $N$. An

\footnotetext{
${ }^{13}$ We cannot simply compare how joint earnings differ because they are identical at $N$ and $E$.
} 
index value of 0 indicates that the pair's division of earnings is half way between what it would be at the two key allocations. ${ }^{14}$

\section{Table 3 near here}

Table 4 reports the values of these three measures for each treatment. Table 5 reports the $p$ values from non-parametric and Tobit panel regression-based tests that compare whether these values differ by treatment, as predicted by the Nash bargain, entitlement, or equity hypotheses.

\section{Table 4 near here}

\section{Table 5 near here}

Treatment I: In Treatment I, where payoffs are equal at the Nash bargain $(N=E)$, and the backstop equals the status quo $(B=Q)$, agreements had an average distance of just under two units from $N$. Agreements were closer to $N$ than to $E^{*}$, (3.5 units), and the mean index of environmentalist's share of earnings was closer to $N$ than to $E^{*}$, at +0.14 . Indeed, agreements in Treatment I turned out to be closer to $N$ than in any other treatment. Given that $N$ here is consistent with all three bargaining hypotheses, any deviations from it may reflect the complexity of the bargaining task that subjects faced in our within-subject, private information design. Consistent with this view, we note that agreements moved slightly closer on average to $N$, the later in a session Treatment I was experienced (from 2.16 in Round 1 to 1.85 in Round 4).

\footnotetext{
14 This index does not capture the absolute distance of agreements to either key allocation, but rather the relative success of either allocation in predicting earnings shares. Agreements northeast or south-west of the key allocations would yield values capped at -0.3 or +0.3 , but this occurred in only 6 percent of agreements.
} 
Treatment II: In Treatment II, the status quo $Q$ diverges "south-west” from $B$ in favour of the developer. This creates a (Nash-irrelevant) bargaining lens south-west of that defined by $B$, with a 'pseudo' Nash bargain at $(10,10) /(10,10)$. As Table 4 illustrates, this change caused agreements to move south-west on average, consistent with the entitlement hypothesis, but not with conventional Nash or egalitarian bargaining. As confirmed by all but one of the signed rank and regression-based tests in Table 5, Treatment II agreements were significantly further from $N$ than those in Treatment I, significantly closer to $(10,10) /(10,10)$; and they resulted in the environmentalists' earnings shares moving significantly closer to what they would have been at $(10,10) /(10,10)$. In short, the allocation that the parties started with influenced the agreements they reached, even though that allocation was not the backstop.

Treatment III: Relative to Treatment I, this treatment changes the rates at which subjects exchange experimental for real currency, causing the payoffs at $B$ and its associated $N$ to become unequal in favour of the environmentalist. Relative to Treatment I, parties seeking to equalize their payoffs would need to move "south-west" from $N$, at $(13,13) /(7,7)$, to $E^{*}$ (which, at $(10,10) /(10.10)$, lies outside the bargaining lens defined by $B)$. Our findings from this treatment provide some evidence that subjects both wished, and were able, to seek equitable outcomes despite the private information design. From Table 4, and the associated tests in Table 5, it is seen that two of three tests find that agreements in Treatment III were significantly further away from $N$ than in Treatment I, and three of three tests find that the environmentalists' shares of earnings grew significantly closer to what they would have been at $E^{*}$.

Treatment IV: Comparing Treatments IV and III provides a second chance to test for the entitlement effect that arises when $Q$ differs from $B$. Here, however, we examine the effect of a status quo at which parties have equal payoffs on support for a Nash bargain with unequal 
payoffs. Entitlement effects here would reinforce equity in pulling agreements "south-west" away from $N$, and this is indeed what we find. As indicated by the distance measures in Table 4, agreements in Treatment IV were closer on average to $E^{*}$ than in any other treatment. Indeed, as Table 2 indicates, a full 32 percent of agreements in Treatment IV were exactly at $E^{*}$, in contrast to 12 percent in Treatment III. The move from $N$ towards $E^{*}$ and its associated distributional effects is significant in all tests in Table 5.

Similarly, comparing Treatments IV and II gives us a second chance to test for aversion to an $N$ with unequal payoffs, now when $Q$ differs from $B$. Perhaps because of the additional complexity brought by the divergence of $Q$ from $B$, the moderate support we found previously for inequality aversion is now only suggestive. Although the mean distance of agreements away from $N$ rises from 3.26 in Treatment II to 3.72 in Treatment IV, the change is not significant in any of our three statistical tests in Table 5. Similarly, although the mean distance from $E^{*}$ falls from 2.88 to 2.41 , and the earnings index falls from -.03 to -.08 , these changes too are not significant.

\subsection{Comparing Motivating Factors}

Nash bargain: Our results provide little support for the Nash bargain under private information. On the one hand, as Harsanyi's model predicts, we find that in most cases our subjects are able to reach agreements that are both Pareto improving (relative to $B$ ) and "close” to Pareto efficient. On the other hand, we find that when the status quo differs from the backstop (and, to a lesser extent, when the equal payoff outcome differs from the Nash bargain), agreements are drawn away from the Nash bargain, often becoming Pareto inferior to the backstop. 
Equity: Our ex ante hypothesis was that under private information, subjects would have difficulty selecting the outcome that equalizes payoffs, even if that were their goal, as they lacked credible information about one another's payoff functions. This appears to be confirmed if we compare the complex $Q \neq B$ environment of Treatments IV vs. II, as introducing an $N$ with unequal payoffs caused no significant movement away from $N$ or towards $E^{*}$. However, if we compare the simpler $Q=B$ environment of Treatments I vs. III, there is significant evidence of movement away from $N$, and of an increase in the disadvantaged party's share of earnings.

Entitlement: We hypothesized that bargainers would act as if one, or both, of them was "entitled" to the status quo so that agreements would be drawn away from the bargaining lens conditioned on the backstop. Comparisons of Treatment II with I and of Treatment IV with III support this hypothesis as, in both cases, the status quo allocation has a significant effect on the agreements reached by the parties. Indeed, this effect is sufficiently strong that subjects are often induced to accept outcomes that are Pareto inferior to the new backstop.

\section{DISCUSSION}

Although there is now an extensive literature on collaborative environmental negotiation, very few of the hypotheses arising from this literature have been tested. This lacuna has arisen because it has been difficult to measure the benefits that participants obtain from bargained outcomes, and because numerous extraneous factors have affected the bargaining process. The purpose of this paper has been to provide tests of some of the literature's hypotheses using a controlled experiment that incorporates the most important characteristics of environmental cooperative bargaining. These include: that environmental policies are composed of multiple characteristics (thereby creating the opportunity for parties to "trade off" policy dimensions even 
when cash side payments are not permissible); and that parties are not well informed about one another's payoff functions.

In so far as lab experiments can shed light on field bargaining, we find that collaborative negotiation is promising. Even though we provide our subjects with roughly two hundred allocations from which to choose, give them only limited time to negotiate, and provide them with only very limited information about their opponents’ preferences, they are able to reach agreements in a high percentage of cases (between 72 and 85 percent) and choose agreements that secure most of the potential gains from trade compared to the backstop (90 to 97 percent). At the same time, we also find that entitlement effects are surprisingly strong and that subjects do not appear to be drawn to the Nash bargain. We conclude that environmental collaborative negotiation holds promise for the creation of mutually-acceptable, Pareto improving policies even if parties are unable to credibly reveal their preferences to one another.

\section{References}

Aengst Peter, Anderson Jeremy, Chamberlin Jay, Christopher Grunewald, Susan Loucks, Elizabeth Wheatley, and Stefen Yaffee (1997) Introduction to conservation planning. Endangered Species Update 14 (7\&8): 5-9

Ansell Chris, Gash Allison (2007) Collaborative governance in theory and practice. Journal of Public Administration Research and Theory 18: 543-571

Bazerman Max (1985) Norms of distributive justice in interest arbitration. Industrial and Labor Relations Review 38: 558-570.

Bazerman, Max, Magliozzi, Thomas, and Neale, Margaret (1985) Integrative bargaining in a competitive market. Organizational Behavior and Human Decision Processes 35: 294-313. 
Beierle T (2000) The quality of stakeholder-based decisions: lessons learned from the case study record, Resources for the Future, Washington, D.C., Discussion Paper 00-56

Binmore, Ken, Shaked Avner, Sutton John (1989) An outside option experiment. Quarterly Journal of Economics 104: 753-70

Bolton, Gary, Ockenfels Axel (2000) ERC: a theory of equity, reciprocity, and competition. American Economic Review 90: 166-193.

Bruce Christopher, Clark Jeremy (2010) The efficiency of direct public involvement in environmental policy making: an experimental test. Environmental and Resource Economics 45: $157-182$

Bruce Christopher, Clark Jeremy (2012) The impact of entitlements and equity on cooperative bargaining: an experiment. Economic Inquiry 50: 867-879.

Chess Caron, Purcell Kristen (1999) Public participation and the environment: do we know what works? Environmental Science and Technology 33: 2685-2692

Coglianese Cary (1997) Assessing consensus: the promise and performance of negotiated rulemaking. Duke Law Journal 46: 1255-1349

Fehr Ernst, Schmidt Klaus (1999) A theory of fairness, competition, and cooperation. Quarterly Journal of Economics 114: 817-868

Gachter Simon, Riedl Arno (2005) Moral property rights in bargaining with infeasible claims. Management Science 51: 249-263

Harsanyi John (1977) Rational behavior and bargaining equilibrium in games and social situations. Cambridge University Press, New York 
Hoffman Elizabeth, Spitzer Matthew (1985) Entitlements, rights, and fairness: an experimental examination of subjects' concepts of distributive justice. Journal of Legal Studies 14: 259298

Hoffman Elizabeth, McCabe Kevin, Smith Vernon (1996) Social distance and other-regarding behavior in dictator games. American Economic Review 86: 653-650

Holt Charles, Laury Susan (2002) Risk aversion and incentive effects. American Economic Review 92: 1644-1655.

Holzinger Katharina (2000) Limits of co-operation: a German case of environmental mediation. European Environment 10: 293-305

Kenney Douglas (2000) Arguing About Consensus. Natural Resources Law Centre, University of Colorado School of Law, Boulder, Colorado

Lax David, Sebenius James (1985) The power of alternatives or the limits to negotiation. Negotiation Journal, 1: 1985

Leach William, Pelkey Neil, Sabatier Paul (2002) Stakeholder partnerships as collaborative policymaking: evaluation criteria applied to watershed management in California and Washington. Journal of Policy Analysis and Management 21: 645-670

Lubell Mark Leach W (2005) Watershed partnerships: evaluating a collaborative form of public participation. National Research Council on Public Participation in Environmental Assessment and Decision Making, Washington, D.C., February 3-4

Lubbers Jeffrey (2007-2008) Achieving policymaking consensus: the (unfortunate) waning of negotiated rulemaking. South Texas Law Review 49: 987-1017

Madani Kaveh (2010) Game theory and water resources. Journal of Hydrology 381: 225-238 
Murnighan J. Keith, Roth Alvin, Schoumaker Francoise (1988) Risk aversion in bargaining: an experimental study. Journal of Risk and Uncertainty 1: 101-124.

Murnighan, J. Keith, Babcock, Linda, Thompson Leigh, and Pillutla, Madan (1999) The information dilemma in negotiations: Effects of experience, incentives, and integrative potential. International Journal of Conflict Management 10: 313-339.

Nash John (1950) The bargaining problem. Econometrica 18: 155-62

Nozick Robert (1974) Anarchy, State, and Utopia. Basic Books, New York

Nydegger, Rudy, Owen G (1975) Two-person bargaining: an experimental test of the Nash axioms. International Journal of Game Theory 3: 239-249

Pritzker David, Dalton D (1995) Negotiated rulemaking sourcebook. Washington, D.C.: Administrative Conference of the United States, September.

Reed Mark (2008) Stakeholder participation for environmental management: a literature review. Biological Conservation 141: 2417-2431.

Rhoads, Thomas. and Shogren, Jason (2001) Coasean bargaining in collaborative environmental policy; in Heyes, A., ed., The Law and Economics of the Environment. Northampton, MA, Edward Elgar, 18-43.

Rhoads, Thomas. and Shogren, Jason (2003) Regulation through collaboration: final authority and information symmetry in environmental Coasian bargaining. Journal of Regulatory Economics 24: 63-89

Roth Alvin (1995) Bargaining experiments. In: Kagel J and Roth A (eds) The handbook of experimental economics. Princeton University Press, Princeton 253-348

Roth A, Malouf Michael (1979) Game-theoretic models and the role of information in bargaining. Psychological Review 86: 574-594 
Roth A, Malouf Michael, Murninghan J. Keith (1981) Sociological versus strategic factors in bargaining. Journal of Economic Behavior and Organization 2: 153-177

Schelling Thomas (1960) The strategy of conflict. Harvard University Press, Cambridge MA

Shogren Jason (1997) Self-interest and equity in a bargaining tournament with non-linear payoffs. Journal of Economic Behavior and Organization 32: 383-394

Susskind Lawrence, Ozawa Connie (1983) Mediated negotiation in the public sector. American Behavioral Scientist 27: 255-279

U.S. Fish and Wildlife Service (2005) Habitat conservation planning. Washington, D.C.

Zajac, Edward (1995) Political economy of fairness. MIT Press, Cambridge, MA

Zeuthen, Frederik (1930) Problems of monopoly and economic warfare. Routledge \& Kegan Paul: London. 
FIGURE 1 An Edgeworth Box Representation of Cooperative Bargaining

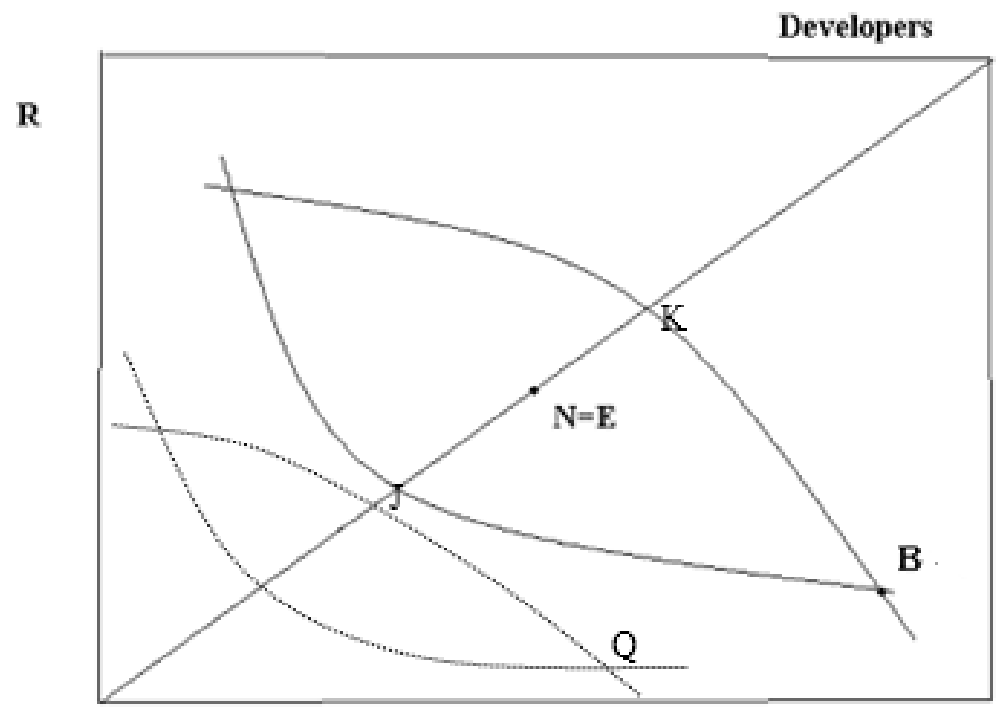

Environmentalists 
FIGURE 2 A Payoff Table Denominated in Experimental Currency (Environmentalist, Treatment II)

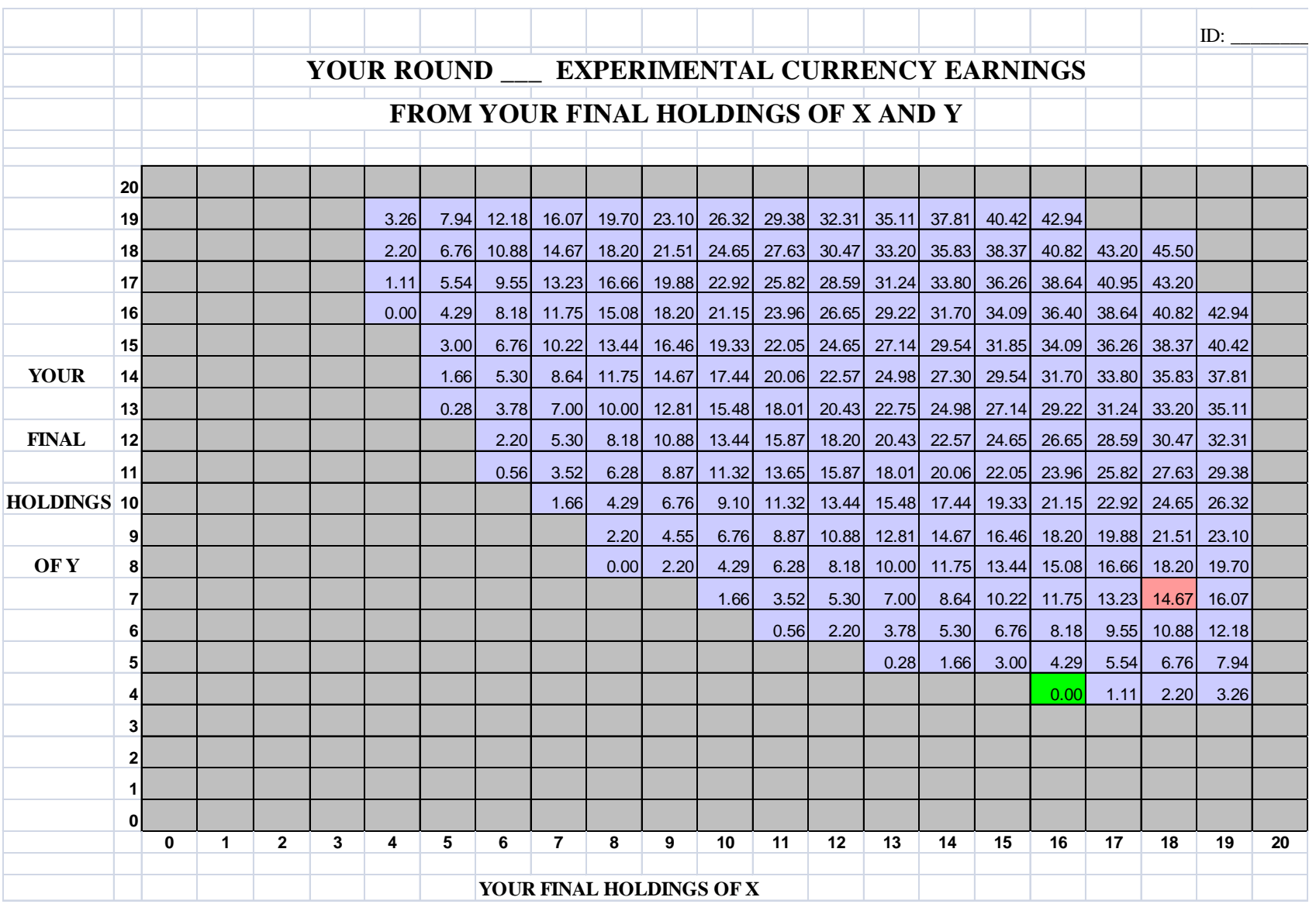


FIGURE 3 Observations from Rounds 2 through 4, Treatments I through IV

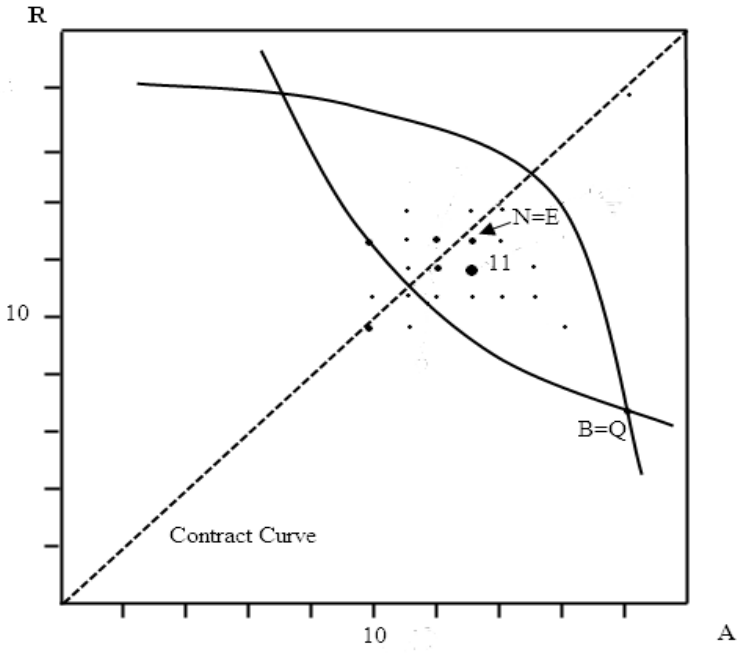

Treatment I: $B=Q ; N=E$

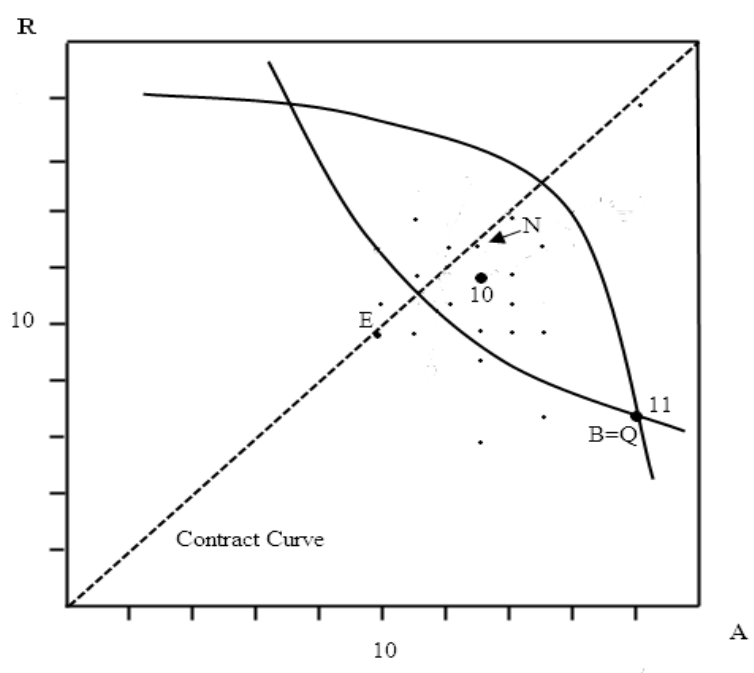

Treatment III: $B=Q ; N \neq E$

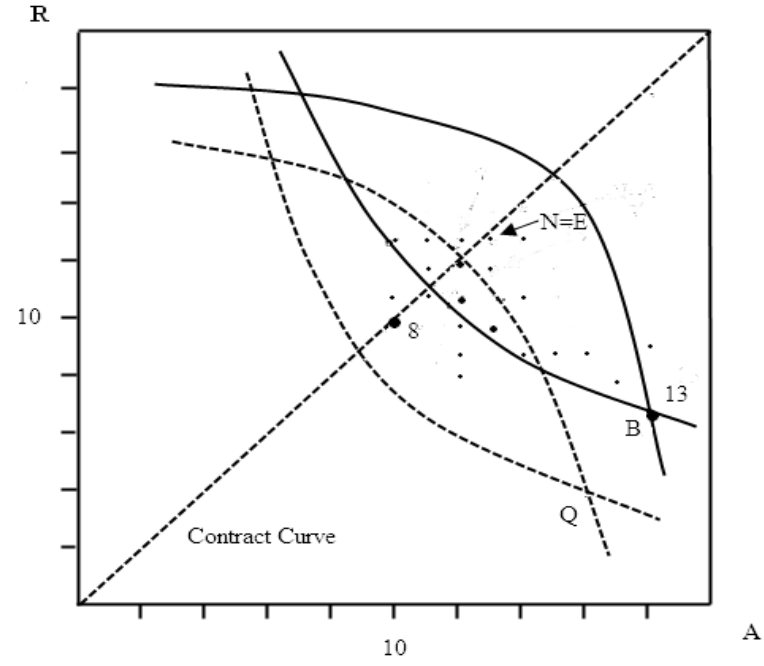

Treatment II: $\mathrm{B} \neq \mathrm{Q} ; \mathrm{N}=\mathrm{E}$

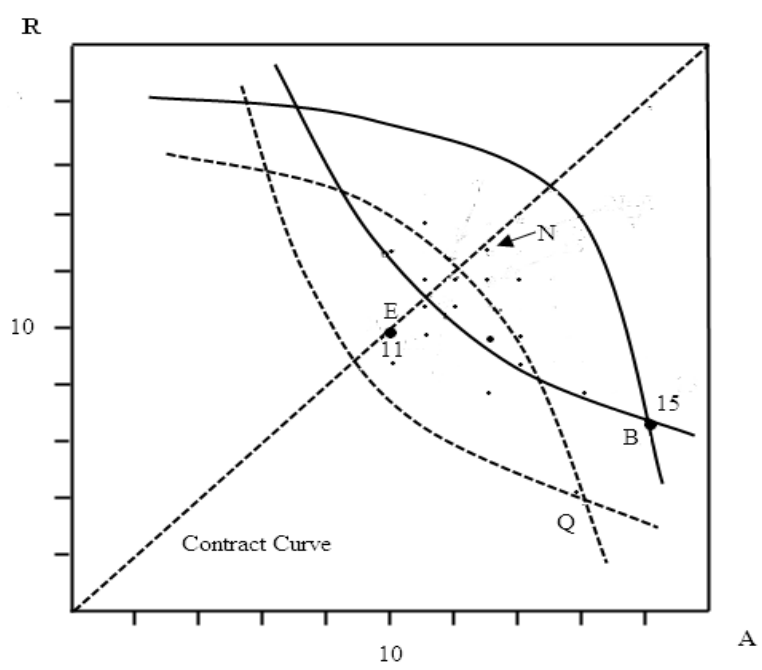

Treatment IV: $\mathrm{B} \neq \mathrm{Q} ; \mathrm{N} \neq \mathrm{E}$

Note: $n=60$ in each of Treatments, II, and III; $n=58$ in Treatment IV.

Legend:

- 1-3 observations

- 4-6 observations

- $\quad 7+$ observations 
TABLE 1: Parameters Used Across Treatments

All Treatments: $\quad$ Environmentalist

Exp. Currency Fcn:

Treatment I:

$(Q=B, N=E)$

Exchange Rate: $\quad$ NZ\$ $=1 *$ ExpCurr +0

At $Q(=B)$ :

At $N(=E)$ :

Treatment II:

$(Q \neq B, N=E)$

Exchange Rate: $\quad$ See Treatment I.

At $Q$ :

At $B$ :

At $N(=E)$ :

Treatment III:

$(\mathrm{Q}=\mathrm{B}, \mathrm{N} \neq \mathrm{E})$

Exchange Rate: $\quad$ NZ\$ $=1 *$ ExpCurr $+\$ 13.65$

At $Q(=B)$ :

At $N$ :

At $E$ :

Treatment IV: $(\mathrm{Q} \neq B, \mathrm{~N} \neq \mathrm{E})$

Exchange Rate: See Treatment III.

At $Q$ :

At $B$ :

At $N$ :

At $E$ :

\section{Environmentalist}

Gets \$14.67 from $(18,7)$

Gets \$22.75 from $(13,13)$

Gets \$ 0.00 from $(16,4)$

Gets $\$ 14.67$ from $(18,7)$

Gets $\$ 22.75$ from $(13,13)$

Environmentalist

Gets \$28.32 from $(18,7)$

Gets \$36.40 from $(13,13)$

Gets $\$ 22.75$ from $(10,10)$
Developer

$U_{D e v}(X, Y)=4.55 X^{1 / 2} Y^{1 / 2}-9.11$

\section{Developer}

$\mathrm{NZ \$}=1 *$ ExpCurr +0

Gets $\$ 14.10$ from $(2,13)$

Gets $\$ 22.75$ from $(7,7)$

\section{Developer}

See Treatment I.

Gets $\$ 27.30$ from $(4,16)$

Gets $\$ 14.10$ from $(2,13)$

Gets $\$ 22.75$ from $(7,7)$

\section{Developer}

$\mathrm{NZ} \$=1 *$ ExpCurr $-\$ 13.65$

Gets \$ 0.45 from $(2,13)$

Gets \$ 9.10 from $(7,7)$

Gets $\$ 22.75$ from $(10,10)$

\section{Developer}

See Tretament III.

Gets $\$ 13.65$ from $(4,16)$

Gets \$ 0.45 from $(2,13)$

Gets \$ 9.10 from $(7,7)$

Gets $\$ 22.75$ from $(10,10)$ 


\section{TABLE 2: Descriptive Statistics of Pair Bargaining Outcomes}

\section{Overall By Round When Exposed To Treatment}

$\begin{array}{lcccc} & \mathbf{1} & \mathbf{2} & \mathbf{3} & \mathbf{4} \\ \mathrm{N}=20 & \mathrm{~N}=20 & \mathrm{~N}=20 & \mathrm{~N}=20^{1} & \mathrm{~N}=20\end{array}$

\section{Agreement Rates}

$\begin{array}{lllllll}\text { T I: } & Q=B, E=N & .85 & .60 & .85 & 1.00 & .95 \\ \text { T II: } & Q \neq B, E=N & .73 & .55 & .55 & .85 & .95 \\ \text { T III: } Q=B, E \neq N & .85 & .90 & .75 & .80 & .95 \\ \text { T IV: } & Q \neq B, E \neq N & .72 & .60 & .65 & .83^{1} & .80\end{array}$

Proportion in Bargaining Lens:

$\begin{array}{lllllll}\text { T I: } & Q=B, E=N & .89 & .95 & .85 & .85 & .90 \\ \text { T II: } \quad Q \neq B, E=N & .74 & .70 & .75 & .70 & .80 \\ \text { T III: } Q=B, E \neq N & .78 & .75 & .80 & .75 & .80 \\ \text { T IV: } Q \neq B, E \neq N & .65 & .55 & .65 & .67^{1} & .75\end{array}$

\section{Contingent on Reaching Agreement:}

\section{Proportion exactly on the Contract Curve:}

$\begin{array}{lllllll}\text { T I: } & Q=B, E=N & .26^{2} & .08 & .29 & .25 & .37 \\ \text { T II: } & Q \neq B, E=N & .31 & .27 & .36 & .29 & .32 \\ \text { T III: } & Q=B, E \neq N & .24 & .17 & .20 & .38 & .21 \\ \text { T IV: } & Q \neq B, E \neq N & .45 & .67 & .38 & .53 & .25\end{array}$

\section{Proportion exactly at the Nash Bargain $(13,13) /(7,7)$ :}

$\begin{array}{lllllll}\text { T I: } & Q=B, E=N & .04^{2} & .00 & .06 & .05 & .05 \\ \text { T II: } & Q \neq B, E=N & .02 & .00 & .00 & .00 & .05 \\ \text { T III: } & Q=B, E \neq N & .03 & .06 & .00 & .06 & .00 \\ \text { T IV: } & Q \neq B, E \neq N & .02 & .00 & .00 & .07 & .00\end{array}$

\section{Proportion exactly at $(10,10) /(10,10)$ (Equalizes Earnings in III, IV):}

$\begin{array}{lllllll}\text { T I: } & Q=B, E=N & .07^{2} & .08 & .06 & .10 & .05 \\ \text { T II: } & Q \neq B, E=N & .19 & .27 & .27 & .18 & .11 \\ \text { T III: } & Q=B, E \neq N & .12 & .11 & .07 & .13 & .16 \\ \text { T IV: } & Q \neq B, E \neq N & .32 & .58 & .31 & .27 & .19\end{array}$

\footnotetext{
$\mathrm{N}=18$ pairs, because in one session two pairs were given faulty payoff tables for Treatment IV when it was implemented as Round 3.

${ }^{2}$ Average calculated over 16 equally weighted session rates, though sessions contained different numbers of pairs reaching agreement for a given round.
} 
TABLE 3: Geometric Distance and Loss in Earnings between Agreements and the Nearest Point on the Contract Curve

Treatment

\begin{tabular}{|c|c|c|c|c|c|c|c|}
\hline & & & & 1 & 2 & 3 & 4 \\
\hline \multirow[t]{2}{*}{$\mathrm{I}$} & $(\mathrm{Q}=\mathrm{B} ; \mathrm{N}=\mathrm{E})$ & $\begin{array}{l}\text { Mean Distance } \\
\text { to Contract Curve }\end{array}$ & $\begin{array}{c}.998 \\
(1.002)^{1}\end{array}$ & $\begin{array}{c}1.473 \\
(1.223)\end{array}$ & $\begin{array}{c}.957 \\
(1.116)\end{array}$ & $\begin{array}{c}.849 \\
(.781)\end{array}$ & $\begin{array}{r}.893 \\
(.938)\end{array}$ \\
\hline & & $\begin{array}{l}\text { Mean Loss (NZ\$) in } \\
\text { Joint Earnings }\end{array}$ & $\begin{array}{l}.50 \\
(.88)\end{array}$ & $\begin{array}{c}.90 \\
(1.23)\end{array}$ & $\begin{array}{c}.53 \\
(1.14)\end{array}$ & $\begin{array}{c}.32 \\
(.52)\end{array}$ & $\begin{array}{l}.40 \\
(.59)\end{array}$ \\
\hline \multirow[t]{2}{*}{ II } & $(\mathrm{Q} \neq \mathrm{B} ; \mathrm{N}=\mathrm{E})$ & $\begin{array}{l}\text { Mean Distance } \\
\text { to Contract Curve }\end{array}$ & $\begin{array}{l}1.646 \\
(2.010)\end{array}$ & $\begin{array}{r}2.443 \\
(3.104)\end{array}$ & $\begin{array}{c}1.479 \\
(1.687)\end{array}$ & $\begin{array}{l}1.373 \\
(1.648)\end{array}$ & $\begin{array}{l}1.526 \\
(1.720)\end{array}$ \\
\hline & & $\begin{array}{l}\text { Mean Loss (NZ\$) in } \\
\text { Joint Earnings }\end{array}$ & $\begin{array}{c}1.69 \\
(3.87)\end{array}$ & $\begin{array}{r}3.69 \\
(7.18)\end{array}$ & $\begin{array}{l}1.18 \\
(1.95)\end{array}$ & $\begin{array}{r}1.14 \\
(2.57)\end{array}$ & $\begin{array}{l}1.33 \\
(2.77)\end{array}$ \\
\hline \multirow[t]{2}{*}{ III } & $(\mathrm{Q}=\mathrm{B} ; \mathrm{N} \neq \mathrm{E})$ & $\begin{array}{l}\text { Mean Distance } \\
\text { to Contract Curve }\end{array}$ & $\begin{array}{l}1.457 \\
(1.739)\end{array}$ & $\begin{array}{c}1.852 \\
(2.193)\end{array}$ & $\begin{array}{r}1.320 \\
(1.411)\end{array}$ & $\begin{array}{c}1.458 \\
(1.834)\end{array}$ & $\begin{array}{l}1.191 \\
(1.454)\end{array}$ \\
\hline & & $\begin{array}{l}\text { Mean Loss (NZ\$) in } \\
\text { Joint Earnings }\end{array}$ & $\begin{array}{c}1.28 \\
(3.28)\end{array}$ & $\begin{array}{l}2.04 \\
(5.31)\end{array}$ & $\begin{array}{l}1.86 \\
(1.55)\end{array}$ & $\begin{array}{l}1.33 \\
(2.45)\end{array}$ & $\begin{array}{l}.87 \\
(2.40)\end{array}$ \\
\hline \multirow{2}{*}{\multicolumn{2}{|c|}{ IV $\quad(\mathrm{Q} \neq \mathrm{B} ; \mathrm{N} \neq \mathrm{E})$}} & $\begin{array}{l}\text { Mean Distance } \\
\text { to Contract Curve }\end{array}$ & $\begin{array}{c}1.414 \\
(1.883)\end{array}$ & $\begin{array}{c}.707 \\
(1.206)\end{array}$ & $\begin{array}{l}1.577 \\
(1.852)\end{array}$ & $\begin{array}{r}1.179 \\
(1.725)\end{array}$ & $\begin{array}{r}2.033 \\
(2.351)\end{array}$ \\
\hline & & $\begin{array}{l}\text { Mean Loss (NZ\$) in } \\
\text { Joint Earnings }\end{array}$ & $\begin{array}{c}1.35 \\
(3.08)\end{array}$ & $\begin{array}{l}.47 \\
(.93)\end{array}$ & $\begin{array}{c}1.37 \\
(2.74)\end{array}$ & $\begin{array}{c}1.02 \\
(2.12)\end{array}$ & $\begin{array}{c}2.30 \\
(4.71)\end{array}$ \\
\hline
\end{tabular}
the Treatment
Associated Test P Values: $\quad$ Sign Rank Test

( $\mathrm{N}=16$ session averages for each treatment)
Comparing Treatment Coefficients
Pair Average Pair Difference Specification $^{2} \quad$ Specification $^{2}$ $\mathrm{N}=250 \quad \mathrm{~N}=250$

Mean Distance to CC:

Overall

\section{By \\ By Round When Exposed to}


TABLE 4: Mean Distance and Relative Deviation in Environmentalist's Share of Earnings between Agreements and Two Key Allocations

\begin{tabular}{|c|c|c|c|c|c|c|}
\hline \multirow[t]{2}{*}{ Treatment } & & \multirow[t]{2}{*}{ Overall } & \multicolumn{4}{|c|}{$\begin{array}{c}\text { By Round When Exposed } \\
\text { to the Treatment }\end{array}$} \\
\hline & & & 1 & 2 & 3 & 4 \\
\hline \multirow[t]{3}{*}{ I $\quad(Q=B ; N=E)$} & $\begin{array}{l}\text { Distance to the Nash } \\
\text { Bargain }(13,13) /(7,7)\end{array}$ & $\begin{array}{l}1.98 \\
(1.29)^{1}\end{array}$ & $\begin{array}{l}2.16 \\
(1.24)\end{array}$ & $\begin{array}{c}2.18 \\
(1.71)\end{array}$ & $\begin{array}{l}1.82 \\
(1.16)\end{array}$ & $\begin{array}{l}1.85 \\
(1.07)\end{array}$ \\
\hline & $\begin{array}{l}\text { Distance to }(10,10) /(10,10) \\
\text { (Not Equal) }\end{array}$ & $\begin{array}{c}3.54 \\
(1.72)\end{array}$ & $\begin{array}{c}3.66 \\
(1.55)\end{array}$ & $\begin{array}{l}3.78 \\
(2.35)\end{array}$ & $\begin{array}{l}3.08 \\
(1.34)\end{array}$ & $\begin{array}{l}3.73 \\
(1.55)\end{array}$ \\
\hline & $\begin{array}{l}\text { Index of Deviation in } \\
\text { Env's Share of Earnings }\end{array}$ & $\begin{array}{c}.14 \\
(.17)\end{array}$ & $\begin{array}{l}.15 \\
(.17)\end{array}$ & $\begin{array}{l}.14 \\
(.16)\end{array}$ & $\begin{array}{c}.11 \\
(.18)\end{array}$ & $\begin{array}{l}.15 \\
(.18)\end{array}$ \\
\hline \multirow[t]{3}{*}{ II $\quad(\mathrm{Q} \neq \mathrm{B} ; \mathrm{N}=\mathrm{E})$} & $\begin{array}{l}\text { Distance to the Nash } \\
\text { Bargain }(13,13) /(7,7)\end{array}$ & $\begin{array}{c}3.26 \\
(1.82)\end{array}$ & $\begin{array}{l}4.32 \\
(2.74)\end{array}$ & $\begin{array}{l}3.20 \\
(1.55)\end{array}$ & $\begin{array}{l}3.17 \\
(1.32)\end{array}$ & $\begin{array}{l}2.75 \\
(1.58)\end{array}$ \\
\hline & $\begin{array}{l}\text { Distance to }(10,10) /(10,10) \\
\text { (Not Equal) }\end{array}$ & $\begin{array}{l}2.88 \\
(2.08)\end{array}$ & $\begin{array}{c}3.19 \\
(3.00)\end{array}$ & $\begin{array}{l}2.86 \\
(2.17)\end{array}$ & $\begin{array}{c}2.43 \\
(1.77)\end{array}$ & $\begin{array}{l}3.11 \\
(1.72)\end{array}$ \\
\hline & $\begin{array}{l}\text { Index of Deviation in } \\
\text { Env's Share of Earnings }\end{array}$ & $\begin{array}{l}-.03 \\
(.20)\end{array}$ & $\begin{array}{l}-.12 \\
(.21)\end{array}$ & $\begin{array}{l}-.01 \\
(.25)\end{array}$ & $\begin{array}{l}-.05 \\
(.17)\end{array}$ & $\begin{array}{c}.04 \\
(.17)\end{array}$ \\
\hline \multirow[t]{3}{*}{ III $\quad(Q=B ; N \neq E)$} & $\begin{array}{l}\text { Distance to the Nash } \\
\text { Bargain }(13,13) /(7,7)\end{array}$ & $\begin{array}{c}2.59 \\
(1.76)\end{array}$ & $\begin{array}{l}2.81 \\
(2.15)\end{array}$ & $\begin{array}{l}2.56 \\
(1.68)\end{array}$ & $\begin{array}{l}2.69 \\
(1.70)\end{array}$ & $\begin{array}{l}2.31 \\
(1.54)\end{array}$ \\
\hline & $\begin{array}{l}\text { Distance to }(10,10) /(10,10) \\
\text { (Equal) }\end{array}$ & $\begin{array}{c}3.31 \\
(1.80)\end{array}$ & $\begin{array}{l}3.55 \\
(2.07)\end{array}$ & $\begin{array}{l}3.17 \\
(1.45)\end{array}$ & $\begin{array}{c}3.44 \\
(1.99)\end{array}$ & $\begin{array}{l}3.08 \\
(1.73)\end{array}$ \\
\hline & $\begin{array}{l}\text { Index of Deviation in } \\
\text { Env's Share of Earnings }\end{array}$ & $\begin{array}{l}.06 \\
(.20)\end{array}$ & $\begin{array}{c}.10 \\
(.21)\end{array}$ & $\begin{array}{l}.05 \\
(.19)\end{array}$ & $\begin{array}{c}.05 \\
(.22)\end{array}$ & $\begin{array}{l}.06 \\
(.21)\end{array}$ \\
\hline \multirow[t]{3}{*}{ IV $(\mathrm{Q} \neq \mathrm{B} ; \mathrm{N} \neq \mathrm{E})$} & $\begin{array}{l}\text { Distance to the Nash } \\
\text { Bargain }(13,13) /(7,7)\end{array}$ & $\begin{array}{c}3.72 \\
(1.83)\end{array}$ & $\begin{array}{l}4.57 \\
(2.24)\end{array}$ & $\begin{array}{l}3.77 \\
(1.29)\end{array}$ & $\begin{array}{l}3.04 \\
(1.57)\end{array}$ & $\begin{array}{l}3.67 \\
(1.97)\end{array}$ \\
\hline & $\begin{array}{l}\text { Distance to }(10,10) /(10,10) \\
\text { (Equal) }\end{array}$ & $\begin{array}{l}2.41 \\
(2.18)\end{array}$ & $\begin{array}{l}1.68 \\
(2.49)\end{array}$ & $\begin{array}{l}2.29 \\
(2.10)\end{array}$ & $\begin{array}{l}2.53 \\
(1.94)\end{array}$ & $\begin{array}{l}2.94 \\
(2.25)\end{array}$ \\
\hline & $\begin{array}{l}\text { Index of Deviation in } \\
\text { Env's Share of Earnings }\end{array}$ & $\begin{array}{l}-.08 \\
(.21)\end{array}$ & $\begin{array}{c}-.18 \\
(.22)\end{array}$ & $\begin{array}{c}-.08 \\
(.20)\end{array}$ & $\begin{array}{l}-.01 \\
(.22)\end{array}$ & $\begin{array}{l}-.05 \\
(.18)\end{array}$ \\
\hline
\end{tabular}

\footnotetext{
${ }^{1}$ Standard deviations in parentheses.

2 Ranges from -0.3, where the environmentalist's share of earnings corresponds to that at $(10,10) /(10,10)$, to +0.3 , corresponding to his share at $(13,13) /(7,7)$.
} 
TABLE 5: P Values from Sign Rank and Regression-Based Tests Comparing Agreements with Two Key Allocations: (Two Sided)

\begin{tabular}{ccc} 
Sign Rank Test & \multicolumn{2}{c}{ Comparing Treatment Coefficients } \\
(N=16 session & Pair Average & Pair Difference \\
averages for each & Specification & Specification \\
treatment) & $\mathrm{N}=250$ & $\mathrm{~N}=250$
\end{tabular}

Mean Distance to the

Nash Bargain $(13,13) /(7,7)$ :

$\mathrm{I}=\mathrm{II}$ ?

0.003

$\mathbf{0 . 0 0 0} 0^{1}$

$\mathbf{0 . 0 0 0} 0^{1}$

$\mathrm{III}=\mathrm{IV} ?$

0.006

0.000

0.000

$\mathrm{I}=\mathrm{III}$ ?

$\mathbf{0 . 0 2 0}$

0.038

0.055

$\mathrm{II}=\mathrm{IV} ?$

0.148

0.312

0.267

Mean Distance to the

Allocation $(10,10) /(10,10)$ :

$\mathrm{I}=\mathrm{II} ?$

0.049

$0.054^{1}$

$0.044^{1}$

$\mathrm{III}=\mathrm{IV} ?$

0.011

0.002

0.003

I = III?

0.196

0.420

0.326

$\mathrm{II}=\mathrm{IV}$ ?

0.179

0.059

0.068

Index of Environmentalists'

Share of Earnings:

$\mathrm{I}=\mathrm{II}$ ?

III = IV?

$\mathrm{I}=\mathrm{III}$ ?

II = IV?
0.001

0.001

0.007

0.215
$0.000^{2}$

0.000

0.040

0.169
$0.000^{2}$

0.000

0.038

0.193

\footnotetext{
'Treatment coefficients estimated from random effects tobit regression of distance of pairs' agreement from specified allocation on treatment, round, order, risk aversion, age, sex, ethnicity, economics course completion, math course completion, English language status, and selfreported grade average. For risk, age and grades, pair averages or differences are tried alternatively. See Appendix B for the regression results.

2 Treatment coefficients estimated from random effects linear regression of index of environmentalists' share of earnings on the same variables as above.
} 